\title{
Insects - a promising feed and food protein source?
}

\author{
Ksenija Nesic ${ }^{1}$ Jutta Zagon² \\ A b s t r a c t: Insect use in feed and food in European countries is now an increasingly debated topic, although these animals \\ have traditionally been nutritional components in Asian, African, Central American and South American cultures. This review ad- \\ dresses the issue of eating insects and using them as feed components, especially considering the nutritionally important factors. Safety \\ risks are also discussed, as well as allergies, toxicity, consumer acceptance, legislative, welfare and environmental concerns and pos- \\ sibilities for laboratory control. Insects play and will play important roles in the future in various fields of research and utilisation, but \\ especially and increasingly as feed and food ingredients.
}

Keywords: edible insects, entomophagy, insect meal.

\section{Introduction}

It has been estimated that the world population will increase by $25 \%$ in the next decades to reach over 9 billion by 2050 (United Nations, 2015). Therefore, a demand to increase food production will be unavoidable, while other influences such as climate change will make this situation more difficult (Nesic, 2018). Recent predictions foresee necessary food augmentation by up to $70 \%$ (Hunter et al., 2017), with a particular need for protein sources. In addition, there has been an approximate fivefold increase in global meat consumption since the 1940s as a result of income growth, increasing urbanisation and changes in lifestyles and food preferences. The Food and Agriculture Organization of the United Nations (FAO) forecasted, in a report from 2003, a worldwide increase in meat consumption from 41.3 to $45.3 \mathrm{~kg}$ capita $^{-1}$ between 2015 and 2030 (FAO, 2003). Meanwhile, recent statistical sources predict much higher figures of global meat consumption, reaching $51.7 \mathrm{~kg} \mathrm{capita}^{-1}$ in 2030 (Statista, 2018). This has also resulted in increasing pressure on the production of protein sources for animal feed. The main protein feedstuffs currently in use are soya and fishmeal, but European countries depend on the import of these ingredients, which makes the livestock sector vulnerable to price inconsistency and trade deviations.

Further deterioration of the situation is the result of the rise in the consumption of fish, as aquaculture is now the fastest growing food production system in the world. This sector mostly relies on fishmeal as a protein source, but fish farms are increasingly looking to crop proteins as a lower-cost replacement for fishmeal. On the other hand, fishmeal is not only used in aquaculture but is also an excellent source of highly digestible protein ideal for poultry and pig diets. Thus, fish and animal farming are together placing growing demands on protein crops and fishmeal supply. Furthermore, issues regarding the availability of land and water put even more pressure on the world's ability to meet the increasing requirements for the production of animal protein (PROTEINSECT, 2016). The response to this escalating problem goes into two directions: to return to previous strategies or to seek new and alternative solutions.

The first option is based on the reintroduction of processed animal proteins (PAP). Besides being from the fish processing industry, these feedstuffs are largely obtained as by-products of dairies and slaughterhouses. Although in principle bearing nutritional value, for safety reasons they have been excluded from the food chain over the years. PAP eradication from the food chain started after the outbreak of bovine spongiform encephalopathy (BSE) in 1986, when it was found that infectious ruminant prions spread by insufficiently processed meat and bone meal (MBM) used as feed. One of the most important measures was to endorse common European rules to avoid entry of these nutrients 
into the food chain (Nesic and Radosavljevic, 2014). As a consequence, several regulations were established and have been continuously modified, repealed or amended over time according to the findings of regularly updated risk assessments. Still, the basic European Union (EU) Regulation (EC) No. 999/2001 (European Union, 2001) generally prohibits, with a few exemptions, the application of PAP in the human and animal food/feed chains. In addition, regulations (EC) No. 1069/2009 (European Union, 2009a) and (EU) No. 142/2011 (European Union, 2011), prescribe general guidelines for the safe use of animal by-products and provide definitions for the various types of materials of animal origin. Furthermore, the use of protein originating from the same species in animal nutrition was forbidden. Such rigorous measures were introduced due to the fact that those ingredients have potential to cause prion infections not only in animals, but also in human populations consuming food of animal origin. Due to the strict approach during more than 20 years, the epidemiological situation in Europe has improved greatly (Paisley et al., 2008). Even in the United Kingdom, a former hotspot of the BSE crisis, the number of officially reported cases declined to zero in 2016 (OIE, 2018), so the possibility of mitigating the ban opened stepwise. Since 2013, the use of non-ruminant PAP, has been approved again in the EU for use in aquaculture (European Union, 2013). Accordingly, on 1 April 2016, amendments to Serbian Regulation on determination, diagnostics and prevention of transmissible spongiform encephalopathies (Serbia, 2016) were published as a result of harmonisation with EU legislation (Nesic et al., 2016; Nesic and Nikolic-Stajkovic, 2016).

In recent years, insects have become increasingly relevant to satisfy the ever growing need for protein in animal feed, and consequently or directly in the food for humans. As a branch of zoology, entomology has a wide spectrum and is a well developed scientific discipline. It includes the biology and control of insects, as well as their ecology and impact on animal, plant and human health. Although they are often considered a nuisance to human beings and mere pests for crops and animals, insects are crucial components of many ecosystems, where they perform very important functions. They aerate the soil, pollinate blossoms and control insect and plant pests. Many insects, especially beetles, are scavengers, feeding on dead corpses and plants, thereby recycling nutrients back into the soil. Based on this role, forensic entomology was developed as an emerging area in forensic science. It has become an important tool in criminal investigations (Amendt et al., 2011). As decomposers, insects help create top nutrient-rich layers of soil that help plants grow and, thus, participate in waste bioconversion. Burrowing bugs, such as ants and beetles, dig tunnels that provide channels for water, benefiting plants. Finally, all insects fertilise the soil with the nutrients from their droppings. Some species produce useful substances, such as honey, wax, lacquer or silk, while some have also been used in medicine. Insects are eaten by many amphibians, reptiles, birds and mammals, making their roles in food chains irreplaceable. Also, it is estimated that they form part of the traditional diets of at least 2 billion people and more than 1,900 species have reportedly been used as food (FAO, 2013).

\section{Insects as feed}

The deficit of protein ingredients, especially for animal feed due to the limited availability of natural resources, ongoing climatic changes, food-feedfuel competition, recent high demand and consequent high prices for fishmeal and soya, increasing production pressure on aquaculture and restrictions on other animal protein usage have led to growing need to include insect protein in diets for aquaculture and livestock. The search for alternative and sustainable proteins is an issue of major importance that requires viable solutions in the short term, making insects an increasingly attractive feed option. Therefore, in mid-2017, the European Commission adopted the amendment EU Regulation No. 2017/893 (European Union, 2017), allowing seven species to be reared and used in feeding aquaculture. This closed list of authorised insects includes: black soldier fly (Hermetia illucens), common housefly (Musca domestica), yellow mealworm (Tenebrio molitor), lesser mealworm (Alphitobius diaperinus), house cricket (Acheta domesticus), banded cricket (Gryllodes sigillatus) and field cricket (Gryllus assimilis). The conditions for the production of insect PAP are strictly regulated. They must be fed only with material of category 3 (material which in principle would still be appropriate for human consumption), not allowing, for example, manure or heavy metal contaminated debris as a feed source. Furthermore, insect PAP has to be treated at least according to method no. 7, following Regulation (EU) No. 142/2011 (European Union, 2011), which means that bacterial contamination must be reduced in order to make a safe product.

The number of new scientific publications on the topic of insects as feed illustrates the growing academic interest, which is also a consequence of the high costs of producing meat, fish and soybean 
meal, i.e., around $70 \%$ of costs in animal production. Therefore, insects, as good sources of nutrients, having a low environmental impact, requiring less space for production and being already part of the natural diets of pigs, poultry and fish, are an ideal feed alternative (Rumpold and Schluter, 2013). The feed conversion efficiency of insects is good, like crickets for example, which require only $2 \mathrm{~kg}$ of feed for every $1 \mathrm{~kg}$ of body weight gain (Collavo et al., 2005). Apart from good quality protein, we can also obtain fat as a by-product of protein production, and which can be considered for making biodiesel (Wang et al., 2017).

In the trial of Newton et al. (2005), when a choice was given, pigs did not discriminate against a diet containing ground soldier fly larvae (Hermetia illucens) compared with soybean meal. Also, recent experiments on piglets (Spranghers et al., 2018) showed that a substantial amount of soybean products (meal and/or toasted beans) can be replaced with black soldier fly without adverse effects on performance. Furthermore, grasshoppers (Acrida cinerea) and Mormon crickets (Anabrus simplex) were also able to replace fishmeal and soybean meal in poultry diets (Wang et al., 2007). In several investigations, it was shown that larvae of the common housefly (Musca domestica), containing 54\% crude protein in dry matter (DM), could successfully replace fishmeal in broiler diets (Teguia et al., 2002; Awoniyi et al., 2004; Hwangbo et al., 2009). When Ijaiya and Eko (2009) replaced 25, 50, 75 or $100 \%$ of fishmeal with silkworm meal in the diet for broilers, they did not find any significant effect on body weight gain, feed intake, feed conversion, slaughtering results or meat quality. In the review of Makkar et al. (2014), 24 feeding experiments (17 from Africa, 4 from Asia and 3 from the USA) with broilers fed various portions of house fly larvae meal (maggot meal) are mentioned. They also included 12 broiler studies $(9$ from India) describing results with silkworm meal. The authors concluded that fishmeal, soybean meal and groundnut cake could be successfully replaced up to $100 \%$ with insect protein.

Insect protein is a suitable replacement for fishmeal in diets for juvenile fish and crustaceans (Riddick, 2014; van Huis et al., 2015). Insects in the form of meal or pellets can provide adequate protein to replace standard fishmeal in feed for omnivorous fish such as carp and catfish. However, there is evidence that in carnivorous fish such as salmon and trout, only a portion of fishmeal can be replaced with insect products (Riddick, 2014). In spite of that, Lock et al. (2016) found an uneven outcome of fish meal replacement in amounts up to $100 \%$ in the diet with two differently processed $H$. illucens meals in feed for Atlantic Salmon (Salmo salar) fed for 15 weeks. The group of fish fed insect meal higher in energy, lipids and carbohydrates performed as well as the fish raised on a fishmeal based diet, whereas fish fed the other insect meal did not. Makkar et al. (2014) reviewed studies with catfish, tilapia, rainbow trout, Atlantic salmon, turbot and crustaceans, where fishmeal was replaced with dried black soldier fly larvae meal, housefly maggots, dried mealworms, locust meal, grasshoppers or silkworm pupae meal. Most studies demonstrated that about $50 \%$ replacement of fishmeal had no adverse effect on animal performance. The research of Devic et al. (2018) concluded that inclusions of up to $80 \mathrm{~g} \mathrm{~kg}^{-1}$ of black soldier fly larvae meal did not affect the feed quality for advanced nursing tilapia. They emphasised that, as the market price of this ingredient is competitive, feed production costs would be alleviated by reducing use of fish meal, fish oil and soyabean meal. More broadly, inclusions of cheaper, sustainable and locally available feedstuffs in juvenile tilapia commercial feed could support the sustainable intensification of aquaculture and contribute more widely to food security.

Regarding other animal species, insects are used as pet food (e.g. crickets for many insectivorous reptiles and amphibians), and are fed alive or prepared in different ways. The recent opinion of the European Food Safety Authority (EFSA, 2015) noted that some insects are low in calcium content, but they are still suitable in such diets as a natural component for these animal groups.

Anyhow, the policy debate recommends focusing primarily on the use of insects in feed for fish, poultry, pigs and pets, while the use of insects in feed for farmed ruminants like cattle is currently not an issue, although the risk for prion transfection by insects is regarded negligible (EFSA, 2015). The overall positive atmosphere surrounding the idea of using insects in animal feed indicates the situation is favourable for moving forward with this development and taking advantage of this opportunity to improve the real and perceived sustainability of animal feed and livestock production (Verbeke et al., 2015).

\section{Insects as food}

The consumption of insects, or entomophagy, is heavily influenced by cultural and religious practices. These animals, as they belong to the kingdom Animalia, are commonly a food source in many regions of the world, especially in Asia, Africa, Central America and South America. In European countries, however, people usually view entomophagy 
with disgust and associate eating insects with rather exotic ethnic habits. This attitude has resulted in the neglect of insects in agricultural research for a long time. Despite historical references to the use of insects for food, the topic of entomophagy has only very recently started to attract public attention worldwide (FAO, 2013). Globally, the most commonly consumed insects are beetles (Coleoptera) (31 percent), caterpillars (Lepidoptera) (18 percent) and bees, wasps and ants (Hymenoptera) (14 percent). Following these are grasshoppers, locusts and crickets (Orthoptera) (13 percent), cicadas, leafhoppers, planthoppers, scale insects and true bugs (Hemiptera) (10 percent), termites (Isoptera) (3 percent), dragonflies (Odonata) (3 percent), flies (Diptera) (2 percent) and other orders ( 5 percent).

Starting in 2018, Regulation (EU) No. $2015 / 2283$ entered into force, laying down provisions for the approval of novel foods in Europe (European Union, 2015). This new regulation establishes the requirements that enable food business operators to bring new food items onto the EU market, while ensuring high levels of food safety for European consumers. Insects, for which no traditional use in the EU is evident, are explicitly mentioned. Thus, for insects, companies have to make an application which is examined and finally approved or rejected by EFSA. However, in certain cases a simpler notification procedure is possible for traditional food from third countries if it is proven that such foods have been part of human nutrition for at least 25 years without any safety concerns. Accordingly, it is reasonable to expect that more insects and insect products will enter the European food market. Interestingly, in Switzerland, an EUassociated partner state, since 1 May 2017, three insect species (Acheta domesticus, Locusta migratoria and Tenebrio molitor) have already been allowed for human consumption. Nevertheless, up to now, there are no systematically collected data available on insect consumption in Europe, although it is known they are used in some elite cuisines, but not comparable with their use in North-Eastern India, South-East Asian countries and parts of Australia. Premalatha et al. (2011) gave some examples: wasps, bamboo caterpillars, cricket and locusts are sold as delicacies in the finest restaurants and food shops in Thailand; annual sales of ant food in China reach \$100 million; the rice field grasshopper, called inago, is a luxury food item in Japan; canned wasps, as a $65 \mathrm{~g}$ can, sell for over $\$ 10$, while hornets are even more expensive, selling at over $\$ 20$ per $100 \mathrm{~g}$. There is an explosion of tourist interest in the native Australian "bush tucker" foods, which include insects such as wichety grubs (Cossidae), bogong moth and bardee larva. In Mexico, upmarket restaurants charge upwards of $\$ 25$ per plate of escamoles (pupae of an ant species) and gusanos (butterfly larvae), and when exported to Canada, escamoles muster a fantastic price of $\$ 50$ for a $30 \mathrm{~g}$ can (almost $\$ 2$ per gram).

Previously, insects were eaten alive and later, in some cultures, they were also served cooked, roasted or boiled (either insects per se or insect additives to food), or prepared using other culinary techniques. Many people prefer incorporating insects into the food in a manner that renders them not visible - only accepting the idea that insects have beneficial nutritional value. This shows that people, especially in North America and Europe, would eat insects if they do not know what they are eating, with the exception of individuals who have allergic reactions (and are aware of possible cross reactions) (Mlcek et al., 2014). These factors suggest that insect transformation, specifically their mode of processing, most certainly would facilitate consumption in the future. In practice, dried insects can be crushed or pulverised, and raw or boiled insects ground or mashed, making their form unrecognisable. Extract of insect protein and fat can also be used. If insects are prepared as masses of protein and lipids, these can be mixed with other foodstuffs, such as grain, ground meat or mashed potatoes to make a variety of dishes and become more acceptable to most people. Insects can also be a serious alternative for vegetarians and though at present rather hypothetical science fiction - their nutritional potential for a relatively long-term future human settlement in space has been discussed (Mlcek et al., 2014).

Among different possibilities for preservation and storage of insects, the most appropriate have to be chosen. Live insects, after washing, are typically transported in ice coolers shortly after collection. Refrigeration is also recommended for fried and boiled insects. Some are preserved and traded after sun-drying. Other simple preservation methods such as acidifying insects with vinegar have been successful. Another example is the use of insects for protein enrichment in fermented food products. This is a viable processing option with mutual benefits, since the decreased $\mathrm{pH}$ in lactic acid-fermented products prevents the growth of potentially harmful microorganisms (Klunder et al., 2012). Sometimes freeze-drying is implemented. However, other contemporary preservation methods should be explored, such as the application of ultraviolet light and high-pressure technologies, as well as adequate packaging methods. For this entire topic, further research on the best, most suitable solutions is necessary. 


\section{Nutritional value}

Insects are usually considered as valuable sources of protein. Because of their high protein content, well balanced amino acid composition and the other nutrients they contain, beside their use as animal feed, they could become an attractive alternative to traditional foods of animal origin, such as milk, meat, fish and eggs in human nutrition. Depending on the insect species, protein levels can be up to $63 \%$ on a DM basis, as is the case with the larvae of black soldier fly (Hermetia illucens) and house fly (Musca domestica), which contain up to around $63 \%$ protein and 36\% fat (Makkar et al., 2014). They contain high levels of key amino acids (e.g. lysine, tryptophan) when compared to most crop plants. A recent study comparing nutritive characteristics of a range of insects showed that the amino acid profile of dipteran insects is superior to soybean meal and more similar to fishmeal (Barroso et al., 2014).

Lipids are a large component of fly larvae with crude fat content in meal produced from house fly larvae reported to range from 14 to $27 \%$ (Fasakin et al., 2003; Aniebo et al., 2008; Pretorius, 2011). The principal fatty acids found in M. domestica larvae and pupae are palmitic, palmitoleic, oleic and linoleic (St-Hilaire et al., 2007; Hwangbo et al., 2009).

Chitin comprises the main carbohydrate in insects. As reviewed by Mlcek et al. (2014), the carbohydrate content of edible insects ranged from $6.71 \%$ to $15.98 \%$. Studies dealing with the vitamin content in insects are insufficient, although it is known that edible insects contain mainly carotene and vitamins B1, B2, B6, D, E, K and C. Analysis of mineral elements showed that edible insects are rich in nutritious elements such as potassium and sodium (e.g. cricket nymph), calcium (e.g. cricket adult), copper (e.g. Usta terpsichore, mealworm adult), iron (e.g. axayacatl - a mixture of several species of aquatic Hemiptera, giant mealworm), zinc (e.g. cricket nymph), manganese (e.g. cricket adult) and phosphorus (e.g. cricket adult). Summarised proximate analysis data by Makkar et al. (2014) and EFSA (2015) on crude nutrients in different insect species are shown in Table 1.

Tables 2 and 3 show some collected data on nutritional composition of insects in comparison to other food protein sources.

As Premalatha et al. (2011) noted, it is a supreme irony that all over the world billions are spent every year to save crops that contain no more than

Table 1. Crude nutrients of different insect species measured by Weende analysis, in $\%$ of dry matter (Adapted from Makkar et al. (2011) and EFSA (2015))

\begin{tabular}{|l|c|c|c|c|}
\hline Insect species & Crude protein \% & Crude fat \% & Carbohydrates \% & Crude ash \% \\
\hline Black soldier fly larvae & $41.1-43.6$ & $15.0-34.8$ & 7.0 & $14.6-26.8$ \\
\hline Housefly maggot meal & $42.3-60.4$ & $9.0-26.0$ & $1.6-8.6$ & $6.2-17.3$ \\
\hline Tenebrio molitor & $47.2-60.3$ & $31.1-43.1$ & $7.4-15.0$ & $1.0-4.5$ \\
\hline Locust or grasshopper meal & $29.2-65.9$ & $4.2-14.1$ & $2.4-14.0$ & $4.4-10.0$ \\
\hline House cricket & $55.0-67.2$ & $9.8-22.4$ & $15.7-22.1$ & $3.6-9.1$ \\
\hline Silkworm pupae meal & $51.6-70.6$ & $6.2-37.1$ & $2.5-5.8$ & $3.3-10.6$ \\
\hline
\end{tabular}

Table 2. B-vitamins in $100 \mathrm{~g}$ servings of chicken and bean dishes in comparison to the content of some insects (Adapted from Premalatha et al. (2011)).

\begin{tabular}{|l|c|c|c|}
\hline & Thiamine & Riboflavin & Niacin \\
\hline Daily human requirement & $1.5 \mathrm{mg}$ & $1.7 \mathrm{mg}$ & $20 \mathrm{mg}$ \\
\hline Portion from roasted chicken & $5.4 \%$ & - & $45 \%$ \\
\hline Portion from backed beans & $10.8 \%$ & - & $3 \%$ \\
\hline Portion from termites & $8.7 \%$ & $67.4 \%$ & $47.7 \%$ \\
\hline Portion from silkmoth larvae & $224.7 \%$ & $112.2 \%$ & $26 \%$ \\
\hline Portion from palm weevil & $201.3 \%$ & $131.7 \%$ & $38.9 \%$ \\
\hline
\end{tabular}


Table 3. Protein and iron in $100 \mathrm{~g}$ servings of beef and of two insects (Adopted from Premalatha et al. (2011)).

\begin{tabular}{|l|c|c|}
\hline Food & Protein, $\mathbf{g}$ & Iron, $\mathbf{~ m g}$ \\
\hline Beef (boiled) & 22.3 & 2.9 \\
\hline Silkmoth larvae (boiled) & 28.2 & 35.5 \\
\hline Grasshoppers (fried) & 61.1 & - \\
\hline
\end{tabular}

$14 \%$ of plant protein by killing another food source (insects) that can contain up to $75 \%$ of high quality animal protein.

\section{What bugs us about edible bugs?}

A major consideration in the use or applicability of any novel food product is to demonstrate its safety. Studies on the microbiological and chemical safety of insects reared for feed and food are limited, but some authors have published review papers on this issue (Belluco et al., 2013; Van der Spiegel et al., 2013), FAO discussed it in its booklet (FAO, 2013), EFSA gave summarised data in its scientific opinion (EFSA, 2015) and project PROTEINSECTS reported their final viewpoint (PROTEINSECTS, 2016). Finally, all of them agree that insects as a feed and food category, in principle, could be consumed with no additional hazards in comparison with usually eaten animal products. Levels of more than 500 potentially toxic chemical contaminants were all below recommended maximum amounts suggested by bodies such as the European Commission, World Health Organisation and Codex. However, elevated levels of the toxic heavy metal cadmium in some insects indicated that pre-screening of rearing substrates would be necessary to mitigate risk. Tests found no evidence of the presence of viable biological contaminants such as Salmonella and Campylobacter (PROTEINSECTS, 2016). On the basis of these facts, insects can be regarded as safe, if properly managed and consumed.

Some toxicological and allergy threats were also considered. Relatively heat-resistant thiaminase was detected and characterised from the silkworm, so it needs thorough heat treatment for detoxification (Nishimune et al., 2000). Pesticide applications against locusts and grasshoppers can cause problems because of their toxic residues (Van Huis, 2003; Yen, 2009). In most cases, allergies to insects are associated with a job where employees deal with insects. In clinical practice in relation to insects, the most commonly reported allergic reactions are to chitin, which is the second most abundant biopolymer in nature (Rop et al., 2009). Crickets can trigger allergic reactions in sensitive consumers (Fernandez-Cassi et al., 2018). Homologue proteins shared between different species can cause such responses. Tropomyosin, arginine-kinase and glyceraldehyde3-phosphate dehydrogenase have been identified as highly allergenic. Hexamerin B1, with allergenic potential requiring more research, has been described as a specific cricket allergen. Pilot results of Broekman et al. (2016) suggest that shrimp-allergic patients might be at risk for mealworm allergy because IgE binding to tropomyosin and arginine kinase (major shellfish allergens) and arcoplasmic calcium-binding protein and myosin light chain (minor shellfish allergens) were detected. For safety reasons, insect food products should be labelled to raise awareness in susceptible consumers.

Consumer acceptance is the key to the successful adoption of insects as a source of protein for feed and food. Recent studies have shown that willingness to eat insect based foods is determined by a diversity of personal attitudes and interests (food neophobia i.e., fear of trying new foods; interest in the environmental impact of personal food choices and; openness to change dietary habits), as well as cultural exposure, familiarity or past experience and knowledge (Verbeke, 2015; Tan et al., 2015). One of the most common refusals is based on hygienic reasons, but most insects, especially edible insects such as grasshoppers and lepidopteran or coleopteran larvae mostly eat fresh plant leaves or wood and are, therefore, cleaner and more hygienic than crabs or lobsters, which eat carrion. In general, the application of insects for food and feed purposes is environmentally more beneficial than traditional sources of proteins (Smetana et al., 2016). Insects can be reared on organic side-streams (including human and animal waste), emit fewer greenhouse gases and less ammonia than cattle or pigs and require significantly less land and water than cattle rearing. As public attention could gradually evolve over time, willingness to adopt the use of insects as nutritive dietary components can modify. Especially, their implementation in animal feed can be expected to evolve.

Other issues such as the welfare of insects raised for use in feed and food also need to be considered. Harvesting insects as food from the wild, 
like any other hunting and collecting activities, has the potential to become a threat to both the target species and the environment. Ramos-Elorduy (2006), for example, reported that the populations of some of the 30 edible insect species in the Mexican town of Tulancalo have declined because of overexploitation, and this situation has led to a call for regulation of edible insects' exploitation in Mexico to ensure better management, production and conservation. Semi-cultivation of edible insects is often used, as well as rearing and farming in various degrees. To ensure animal welfare, farmed insects should be provided with adequate space to minimise mortality and increase productivity. Little is known about the extent to which insects experience pain and discomfort (Erens et al., 2012), but insectkilling methods that would reduce suffering include freezing or instantaneous techniques such as shredding.

Further regulatory aspects have to be solved in the future. Western legislation is greatly focused on safety concerns about new food or new ingredients (Belluco et al., 2013). In addition, there are merely technical difficulties, e.g., regarding slaughterhouse registration, which is not yet applicable to insects, and in relation to the substrate on which the insects are reared. Insects produced for feed would be classed as farmed animals, for which only category 3 materials are allowed as a feed source. Manure is a category 2 material and, therefore, not permitted to be fed to farmed animals; neither can insects be fed on catering waste or former foodstuffs containing meat and/or fish.

As for any other ingredient, adequate monitoring and control of feed and food has to be implemented. However, no laboratory test for their detection in feed/food has been officially validated and standardised yet.

\section{Laboratory control}

Enforcement of any legislation requires adequate analytical tools and implementation of an appropriate control system (Nesic and Pavlovic, 2012). Hence, the design of laboratory methods should serve for monitoring authenticity, control of labels/ declarations and detection of fraud (van Raamsdonk et al., 2017). When it comes to insects that belong to animal protein and are subject to PAP regulations, the only methods authorised for feed testing are light microscopy and polymerase chain reaction (PCR) (European Union, 2013). There is also a corresponding harmonised regulation in Serbia (Serbia, 2016). These two methods are used for aquaculture feed control individually or in combination (EURL$A P, 2015)$, but usually microscopy gives the first information on the presence of PAP material. Light microscopy can distinguish between fish and terrestrial particles, as it relies principally on the categorisation of bone fragments into those two groups. The team of the EU Reference Laboratory for animal proteins in feedstuffs recently proposed an improvement of Annex VI of EU regulation (EC) No. 152/2009 (European Union, 2009b), publishing a modified and adapted microscopy protocol for detection of insects. Furthermore, the implementation of a third category of animal material in addition to terrestrial as "terrestrial invertebrates" was proposed (Veys et al., 2018).

However, microscopic discrimination between authorised species and undesired ones is not possible. Hence, the use of other methods, such as DNA targeting of authorised species, would offer additional information. Polymerase chain reaction (PCR) is the most frequently applied method for reliable detection of species-specific DNA. It has already been officially accepted for ruminant DNA detection in feed (EURL-AP, 2017), and two new protocols for poultry and pig DNA have been validated by the European Union Reference Laboratory for Animal Proteins in Feedingstuffs, but not yet included in the official catalogue of methods. Regarding other animal species detection, PCR has also found a role especially in forensic investigations (Davitkov et al., 2017), while forensic entomology as a scientific discipline developed the application of insects in criminal investigation (Joseph et al., 2011). To unravel food fraud, PCR is the most promising method of choice (Nesic et al., 2017).

To fill the existing analytical gaps and to detect the species of interest rapidly, the most promising approach today is real-time PCR. Recently, three fully validated methods were published. One protocol is to detect in food and feed the beetle Tenebrio molitor (Debode et al., 2017), the larvae of which are allowed for aquaculture feed, but are also a popular pet food for reptiles and birds. Two papers were published on the detection of black soldier fly (Hermetia illucens) in feedstuffs by newly developed real-time PCR methods (Marien et al., 2018; Zagon et al., 2018). However, five other insect species are allowed in feed and for which proper detection and control methods remain to be ascertained, while more than one million species of insects are unable to be discriminated. There is also a challenge in relation to food matrices and, as mentioned by Zagon et al. (2018), it might be expected that sooner or later, insects will be added to the list of commodities in the frame of the European allergen labelling 
directives. To cope with the huge diversity of insects belonging to the big phylum of arthropods, the possibility of multiplexing solutions with other insect-targeted PCR methods could be an option. Alternatively, the application of next-generation sequencing (NGS) based on metabarcoding of arthropods (Deiner et al., 2017; Richardson et al., 2018; Toju and Baba; 2018) can be considered. This powerful technique enables the simultaneous detection of many different species in one and the same DNA extract, as demonstrated for native DNA isolated from environmental samples or faeces from insectivorous animals to evaluate their spectra of insect prey (Sint et al.,2014; Galan et al., 2018). A major challenge in terms of processed materials will be to identify universal primers targeting DNA fragments of suitable size $(\leq 150 \mathrm{bp})$, but at the same time covering all major groups of insects which are at least Diptera, Orthoptera, Lepidoptera and Coleoptera, accounting for the most important cultured insects. Apart from this, sensitivity in the case of only trace amounts of one particular species might be an issue, as could be economic aspects, since NGS machines, consumables and operator's knowledge are significant costs for these tests. The future will show how far and how rapidly this new sequencing method will find its way into routine application.

In any case, DNA-based methods and possibly some other laboratory tests used in feed control, like immunoassays (Nesic et al., 2012), near-infrared spectrometry or mass spectrometry, at present, should probably be used as complementary tests once insect fragments have been microscopically confirmed in a non-specific screening approach (Nesic et al., 2014). This would be a continuation of the present strategy for the disclosure of PAPs in feed (Veys et al., 2018; EFSA, 2018). Nevertheless, different teams worldwide are rapidly pursuing research work and results are expected soon, as feed regulations in this area certainly will reflect on and push forward the science. Surely, food control, in response to future regulative tendencies, will require analytical approaches at the highest level.

Although up to now, no thresholds for PAPs have been implemented, it has to be critically remarked that still no reliable quantitative method exists. DNA-based methods (qPCR) are well suited for relative quantitation (e.g. to express the percent DNA of a given species in relation to DNA of another matrix component), as, for example, in genetically modified organism (GMO) detection. This is easily done if single copy genes are chosen for quantitation, and standard matrices or plasmids are available. Absolute results can be expressed as copy numbers of the DNA fragment under investigation. Further, digital PCR techniques, determining exact copy numbers by separation of DNA targets in multifold reactions, are ideally suited for copy number-based relative quantitation, e.g., as proven for GMO (Koeppel and Bucher, 2015). However, if absolute amounts (gram) of an analyte are to be calculated, the true value is difficult to deduce merely from copy numbers, since the amount of DNA in different tissue types can vary considerably. The bias is worse if, to enhance sensitivity, multi-copy genes (e.g. mitochondrial genes) are targeted by the PCR method. Nonetheless, encouraging results were achieved in estimating the prey-predator relation for sea lions using multi-copy targets in qPCR for species detection in scats (Tollit et al., 2009). This principle might also be an option for discriminating allowed insect species against the background of unknown insect species. However, such quantitative approaches require well-characterised, universal group-specific primers and possibly numerical and empirically evaluated correction factors. Therefore, intensive research in this field is urgently required.

\section{Conclusion}

Based on novel data, insects represent a promising feed and food protein source, but future research needs to provide some solutions before they can be widely utilised in food and/or feed. Clarification is required to determine how the nutritional value of insects can be managed systematically, establish clear processing and storage methodologies, define rearing practices and implement regulations and adequate laboratory control with regard to food and feed safety. Overall, entomophagy can be promoted for several reasons: insects, if reared properly, are in principle, healthy, sustainable and nutritious alternatives to other animal food/feed sources, while insects' low negative environmental influence favours them, and economic factors are also on their side. Last but not least, the decision should be up to the informed consumer, accompanied by thorough risk assessment and correct labelling and controls, whether to accept this kind of novel food and feed in the future. 


\title{
Insekti - potencijalni izvor proteina?
}

\author{
Ksenija Nešić Jutta Zagon
}

A b s tr a kt: Mogućnost upotrebe insekata kao izvora proteina u hrani i hrani za životinje tema je o kojoj se sve više raspravlja u evropskim zemljama, mada su ove životinje tradicionalno korišćene u ishrani u azijskim, afričkim, srednjeameričkim i južnoameričkim kulturama. U radu je predstavljan pregled primene insekata u nutritivne svrhe, a takođe su navedeni potencijalni rizici po bezbednost, alergijski aspekti, toksičnost, prihvatljivost za potrošače, zakonodavstvo, elementi dobrobiti, uticaj na životnu sredinu i mogućnosti za laboratorijsku kontrolu. Insekti imaju mnogobrojne važne uloge u različitim oblastima istraživanja i upotrebe, ali se sve više pominju kao hraniva i prehrambeni sastojci budućnosti.

Ključne reči: entomofagija, jestivi insekti, hrana i hrana za životinje.

Disclosure statement: No potential conflict of interest was reported by authors.

Acknowledgement: Authors express their gratitude to the Guest scientist program (Werner-Baltes-Fellowship) of the German Federal Institute for Risk Assessment (BfR), as well as to the project of the Ministry of Education, Science and Technological Development of the Republic of Serbia III46009 for support of this cooperation.

\section{References}

Amendt, J., Richards, C. S., Campobasso, C. P., Zehner, R. \& Hall, M. J. (2011). Forensic entomology: applications and limitations. Forensic Science, Medicine and Pathology, 7 (4), 379-392.

Aniebo, A. O., Erondu, E. S. \& Owen, O. J. (2008). Proximate composition of housefly larvae (Musca domestica) meal generated from mixture of cattle blood and wheat bran. Livestock Research for Rural Development, 20, 12.

Awoniyi, T. A. M., Adetuyi, F. C. \& Akinyosoye, F. A. (2004). Microbiological investigation of maggot meal, stored for use as livestock feed component. Journal of Food Agriculture and Environment, 2, 104.

Barroso, F. G., de Haro, C., Sánchez-Muros, M-J., Venegas, E., Martínez-Sánchez, A. \& Pérez-Bañón, C. (2014). The potential of various insect species for use as food for fish. Aquaculture, 422-423, 193-201.

Belluco, S., Losasso, C., Maggioletti, M., Alonzi, C. C., Paoletti, M. G. \& Ricci, A. (2013). Edible insects in a food safety and nutritional perspective: A critical review. Comprehensive Reviews in Food Science and Food Safety, 12, 296-313.

Broekman, H., Verhoeckx, K. C., den Hartog Jager, C. F., Kruizinga, A. G., Pronk-Kleinjan, M., Remington, B. C., Bruijnzeel-Koomen, C. A., Houben, G. F. \& Knulst, A. C. (2016). Letters to the Editor: Majority of shrimp-allergic patients are allergic to mealworm, Journal of Allergy and Clinical Immunology, 137 (4), 1261-1263.

Collavo, A., Glew, R. H., Huang, Y.S., Chuang, L. T., Bosse, R. \& Paoletti, M. G. (2005). House cricket small-scale farming. In: Paoletti, M.G. Ecological implications of Minilivestock: Potential of insects, Rodents, Frogs and Snails. Science publisher, New Hampshire, 519-544.
Davitkov, D., Glavinic, U., Nesic, K., Davitkov, D., Vucicevic, M., Nesic, V. \& Stanimirovic, Z. (2017). Improved DNA-based identification of Cervidae species in forensic investigations. Acta Veterinaria-Beograd, 67 (4), 449-458.

Debode, F., Marien, A., Gerard, A., Francis, F., Fumiere, O., \& Berben, G. (2017). Development of real-time PCR tests for the detection of Tenebrio molitor in food and feed. Food Additives \& Contaminants: Part A, 34 (8), 1421-1426.

Deiner, K., Bik, H. M., Machler, E., Seymour, M., Lacoursiere-Roussel, A., Altermatt, F., Creer, S., Bista, I., Lodge, D. M., de Vere, N., Pfrender, M. E. \& Bernatchez, L. (2017). Environmental DNA metabarcoding: Transforming how we survey animal and plant communities. Molecular Ecology, 26 (21), 5872-5895.

Devic, E., Leschen, W., Murray, F. \& Little, D. C. (2018). Growth performance, feed utilization and body composition of advanced nursing Nile tilapia (Oreochromis niloticus) fed diets containing Black Soldier Fly (Hermetia illucens) larvae meal. Aquaculture Nutrition, 24, 416-423.

EFSA. (2015). Risk profile related to production and consumption of insects as food and feed. EFSA Journal, 13 (10), 4257.

EFSA. (2018). Panel on Biological Hazards (BIOHAZ). Updated quantitative risk assessment (QRA) of the BSE risk posed by processed animal protein (PAP), Scientific Opinion, EFSA Journal, 6 (7), 5314.

Erens, J., Es van, S., Haverkort, F., Kapsomenou, E. \& Luijben, A. (2012). A bug's life: large-scale insect rearing in relation to animal welfare: Project 1052. Wageningen, Wageningen University. 
EURL-AP Standard Operating Procedure (2015). Operational protocols combining light microscopy and PCR for the detection of constituents of animal origin in feed materials and compound feed. European Union Reference Laboratory for Animal Proteins in feedingstuffs, Walloon Agricultural Research Centre, Henseval Building, Chaussee de Namur 24, Be 5030 Gembloux http://eurl.craw.eu/ en $/ 187 /$ method-ofreference-and-sops.

EURL-AP Standard Operating Procedure (2017). Detection of ruminant DNA in feed using real-time PCR. V1.2, Publication date 17.08.2017, Applicable on 01.09.2017, European Union Reference Laboratory for Animal Proteins in feedingstuffs, Walloon Agricultural Research Centre, Henseval Building, Chaussee de Namur 24, Be 5030 Gembloux http://eurl.craw.eu/en/187/method-ofreference-and-sops.

European Union (2001). Regulation (EC) No 999/2001 of the European Parliament and of the Council of 22 May 2001 laying down rules for the prevention, control and eradication of certain transmissible spongiform encephalopathies. Official Journal of the European Communities, L147, 1-40.

European Union (2009a). Regulation (EC) No 1069/2009 of the European parliament and of the council of 21 October 2009 laying down health rules as regards animal by-products and derived products not intended for human consumption and repealing Regulation (EC) No 1774/2002 (Animal by-products Regulation). Official Journal of the European Union, L300, 1-33.

European Union (2009b). Commission regulation (EC) No $152 / 2009$ of 27 January 2009 laying down the methods of sampling and analysis for the official control of feed. Official Journal of the European Union, L54/1, 1-130.

European Union (2011). European Commission. Commission regulation (EU) No 142/2011 of 25 February 2011 implementing Regulation (EC) No 1069/2009 of the European Parliament and of the Council laying down health rules as regards animal by-products and derived products not intended for human consumption and implementing Council Directive 97/78/EC as regards certain samples and items exempt from veterinary checks at the border under that Directive. Official Journal of the European Union, L54, 1-254.

European Union (2013). Regulation (EC) No 51/2013 of 16 January 2013 amending Regulation (EC) No 152/2009 as regards the methods of analysis for the determination of constituents of animal origin for the official control of feed. Official Journal of the European Union, L20, 33-43.

European Union (2015). Regulation (EU) No 2015/2283 of 25 November 2015 on novel foods, amending Regulation (EU) No 1169/2011 and repealing Regulation (EC) No 258/97 and Commission Regulation (EC) No 1852/2001. Official Journal of the European Union, L327, 1-22.

European Union (2017). Regulation (EU) No 2017/893 of 24 May 2017 amending annexes I and IV to regulation (EC) No 999/2001 of the European Parliament and of the Council and annexes X, XIV and XV to commission regulation (EU) No 142/2011 as regards the provisions on processed animal protein. Official Journal of the European Union, L138, 92-116.

FAO (2003). World agriculture: towards 2015/20130. An FAO perspective. Earth Scan Publications Ltd., London. ISBN 9251048355O. Online publication: http://www.fao.org/ docrep/pdf/005/y4252e/y4252e.pdf
FAO (2013). Edible insects: future prospects for food and feed security, FAO, UN http://www.fao.org/docrep/018/ i3253e/i3253e.pdf.

Fasakin, E. A., Balogun, A. M. \& Ajayi, O. O. (2003). Evaluation of full-fat and defatted maggot meals in the feeding of clariid catfish Clarias gariepinus fingerlings. Aquaculture Research, 34 (9), 733-738.

Fernandez-Cassi, X., Supenu, A., Jansson, A., Boqvist, S. \& Vagsholm, I. (2018). Novel foods: a risk profile for the house cricket (Acheta domesticus). EFSA Journal,16(S1):e16082.

Galan, M., Pons, J. B., Tournayre, O., Pierre, E., Leuchtmann, M., Pontier, D. \& Charbonnel, N. (2018). Metabarcoding for the parallel identification of several hundred predators and their prey: Application to bat species diet analysis. Molecular Ecology_Resources 18 (3), 474-489.

Hunter, M. C., Smith, R. G., Schipanski, M. E., Atwood, L.W. \& Mortensen, D. A. (2017). Agriculture in 2050: Recalibrating targets for sustainable intensification. BioScience, 67 (4), 386-391.

Hwangbo, J., Hong, E. C., Jang, A., Kang, H. K., Oh, J. S., Kim, B. W. \& Park, B. S. (2009). Utilization of house flymaggots, a feed supplement in the production of broiler chickens. Journal of Environmental Biology, 30, 609-614.

Ijaiya, A. T. \& Eko, E. O. (2009). Effect of replacing dietary fish meal with silkworm (Anaphe infracta) caterpillar meal on performance, carcass characteristics and haematological parameters of finishing broiler chicken. Pakistan Journal of Nutrition, 8, 850-855.

Joseph, I., Mathew, D. G., Sthyan, P., \& Vargheese, G. (2011). The use of insects in forensic investigations: An overview on the scope of forensic entomology. Journal of Forensic Dental Sciences, 3(2), 89-91.

Klunder, H.C., Wolkers-Rooijackers, J., Korpela, J. M. \& Nout, M. J. R. (2012). Microbiological aspects of processing and storage of edible insects. Food Control, 26, 628-631.

Koeppel, R. \& Bucher, T. (2015). Rapid establishment of droplet digital PCR for quantitative GMO analysis. European Food Research and Technology, 241(3), 427-439.

Lock, E. R., Arsiwalla, T. \& Waagbo, R. (2016). Insect larvae meal as an alternative source of nutrients in the diet of Atlantic salmon (Salmo salar) post-smolt. Aquaculture $\mathrm{Nu}$ trition, 22, 1202-1213.

Makkar, H. P. S., Tran, G., Heuze, V. \& Ankers, P. (2014). State-of-the art on use of insects in animal feed. Animal Feed Science and Technology, 197, 1-33.

Marien, A., Debode, F., Aerts, C., Ancion, C., Francis, F. \& Berben, G. (2018). Detection of Hermetia illucens by real-time PCR. Journal of Insects as Food and Feed, 4 (2), 115-122.

Mlcek, J., Rop, O., Borkovcova, M. \& Bednarova, M. (2014). A comprehensive look at the possibilities of edible insects as food in Europe - a review. Polish. Journal of Food and Nutrition Science, 64 (3), 147-157.

Nesic, K. (2018). Mycotoxins - climate impact and steps to prevention based on prediction. Acta Veterinaria-Beograd, 68 (1), 1-15.

Nesic, K., Pavlovic, N. \& Jojic-Malicevic, LJ. (2012). Determination of the presence of meat and bone meal originating from cattle in animal feed using three different commercial immunochemical tests. Meat Technology, 53, (2), 173-178. 
Nesic, K. \& Nikolic-Stajkovic, S. (2016). Recycling of animal by-products within the food chain. Second International Symposium of Veterinary Medicine (ISVM2016), Belgrade, Serbia, Proceedings, 292-298.

Nesic, K. \& Pavlovic N. (2012). Animal health protection through the control of use of animal proteins in feed. The First International Symposium on Animal Science, Belgrade, Serbia, Proceedings, 912-919.

Nesic, K. \& Radosavljevic, V. (2014). Sporedni proizvodi animalnog porekla u ishrani zivotinja: Reciklaza unutar lanca hrane. Ecologica, 74, 303-307.

Nesic, K., Pavlovic, N., Lazic, G. \& Bozic, B. (2016). Monitoring of feed for the presence of animal proteins in Serbia - decade overview and close perspective. Second International Symposium of Veterinary Medicine (ISVM2016), Belgrade, Serbia, Proceedings, 180-188.

Nesic, K., Samanc, H., Vujanac, I., Prodanovic, R., Nesic, V., Velebit, B. \& Savic, B. (2014). Detection of meat and bone meal in cattle feed and ruminal fluid - comparison and combining of microscopy and polymerase chain reaction. Animal Feed Science and Technology, 187, 86-90.

Nesic, K., Stojanovic, D. \& Baltic, M. (2017). Authentication of meat and meat products vs. detection of animal species in feed - what is the difference? 59 $9^{\text {th }}$ International Meat Industry Conference MEATCON2017. IOP Conf. Series: Earth and Environmental Science, 85, 012043.

Newton, L., Sheppard, C., Watson, D.W. \& Burtle, G. (2005). Dried Hermetia illucens larvae meal as supplement for swine. Journal of Animal Science, 44, 395-400.

Nishimune, T., Watanabe, Y., Okazaki, H. \& Akai H. (2000). Thiamin is decomposed due to Anaphe spp. entomophagy in seasonal ataxia patients in Nigeria. The Journal of $\mathrm{Nu}$ trition, 130 (6), 1625-1628.

OIE (2018). Official statistics. http://www.oie.int/en/animalhealth-in-the-world/bse-situation-in-the-world-and-annual-incidence-rate/number-of-cases-in-the-united-kingdom

Paisley, L.G., De Koeijer, A., Hagenaars, T. H., Murray, D., Guarnieri, F., Adkin, A. \& Jacob C. (2008). Risk analysis of Transmissible Spongiform Encephalopathies in animals: state-of-the-art. International Journal of Risk Assessment and Management, 8 (3), 214-242.

Premalatha, M., Abbasi, T., Abbasi, T. \& Abbasi, S. A. (2011). Energy-efficient food production to reduce global warming and ecodegradation: the use of edible insects. Renewable and Sustainable Energy Reviews, 15 (9), 4357-4360.

Pretorius, Q. (2011). The evaluation of larvae of Musca Domestica (common house fly) as protein source for broiler production. MSc Thesis, Faculty of AgriSciences, University of Stellenbosch, South Africa.

PROTEINSECT Final Report Summary (2016). Enabling the exploitation of insects as a sustainable source of protein for animal feed and human nutrition, Grant Agreement No. 312084, $7^{\text {th }}$ EU's Framework Research and Innovation Programme. FERA SCIENCE LIMITED, UK (https://cordis.europa.eu/result/rcn/191985 en.html).

Ramos-Elorduy, J. (2006). Threatened edible insects in Hidalgo, Mexico and some measures to preserve them. Journal of Ethnobiology and Ethnomedicine, 2, 51.

Richardson, R. T., Bengtsson-Palme, J., Gardiner, M. M. \& Johnson, R. M. (2018). A reference cytochrome c oxidase subunit I database curated for hierarchical classification of arthropod metabarcoding data. PeerJ 6:e5126 https://doi.org/10.7717/peerj.5126
Riddick, E. W. (2014). Insect protein as a partial replacement for fishmeal in the diets of juvenile fish and crustaceans. In: Morales-Ramos, J. A., Rojas, M. G. and Shapiro-Ilan, D. I. (eds.). Mass production of beneficial organisms-Invertebrates and Entomopathogens, Academic Press, Amsterdam, Chapter 16, pp. 565-582.

Rop, O., Mlcek, J. \& Jurikova T. (2009). Beta glucans in higher fungi and their health effect. Nutrition reviews, 67, 624-631.

Rumpold, B. A. \& Schluter, O. K. (2013). Nutritional composition and safety aspects of edible insects. Molecular $\mathrm{Nu}$ trition and Food Research, 57 (5), 802-823.

Serbia. (2016). Regulation on determination, diagnostics and prevention of transmissible spongiform encephalopathies. Official Gazette of the Republic of Serbia, 33.

Sint, D., Niederklapfer, B., Kaufmann, R. \& Traugott, M. (2014). Group-Specific Multiplex PCR Detection Systems for the Identification of Flying Insect Prey. PLoS One 9 (12), 1-17.

Smetana, S., Palanisamy, M., Mathys, A. \& Heinz, V. (2016). Sustainability of insect use for feed and food: Life Cycle Assessment perspective. Journal of Cleaner Production, 137, 741-751.

Spranghers, T., Michiels, J., Vrancx, J., Ovyn, A., Eeckhout, M., De Clercq, P. \& De Smet, S. (2018). Gut antimicrobial effects and nutritional value of black soldier fly (Hermetia illucens L.) prepupae for weaned piglets. Animal Feed Science and Technology, 235, 33-42.

St-Hilaire, S., Cranfill, K., McGuire, M. A., Mosley, E. E., Tomberlin, J. K., Newton, L., Sealey, W., Sheppard, C. \& Irving, S. (2007). Fish offal recycling by the black soldier fly produces a foodstuff high in omega-3 fatty acids. Journal of the World Aquaculture Society, 38 (2), 309-313.

Statista (2018). Statista, The Statistics Portal. https://www. statista.com/statistics/502294/glo bal-meat-consumptionby-type/

Tan, H.S.G., Fischer, A.R.H., Tinchan, P., Stieger, M., Steenbekkers, L.P.A. \& van Trijp, H.C.M. (2015). Insects as food: exploring cultural exposure and individual experience as determinants of acceptance. Food Quality and Preference, 42, 78-99.

Teguia, A., Mpoame, M. \& Okourou, M. J. A. (2002). The production performance of broiler birds as affected by the replacement of fish meal by maggot meal in the starter and finisher diets. Tropicultura, 20, 187-192.

Toju, H. \& Baba, Y. G. (2018). DNA metabarcoding of spiders, insects, and springtails for exploring potential linkage between above- and below-ground food webs. Zoological Letters 4, 1-12.

Tollit, D. J., Schulze, A. D., Trites, A.W., Olesiuk, P. F., Crockford, S. J., Gelatt, T. S., Ream, R. R. \& Miller, K. M. (2009). Development and application of DNA techniques for validating and improving pinniped diet estimates. Ecological Applications, 19 (4), 889-905.

United Nations (2015). United Nations, Department of Economic and Social Affairs, Population Division (2015). World Population Prospects: The 2015 Revision, Key Findings and Advance Tables. Working Paper No. ESA/P/ WP.241. https://esa.un.org/unpd/wpp/Publications/Files/ Key Findings WPP 2015.pdf

Van der Spiegel, M., Noordam, M.Y. \& van der Fels-Klerx, H. J. (2013). Safety of novel protein sources (insects, microalgae, seaweed, duckweed, and rapeseed) and 
legislative aspects for their application in food and feed production. Comprehensive Reviews in Food Science and Food Safety, 12, 662-678.

Van Huis, A. (2003). Insects as food in sub-Saharan Africa. Insect Science and its Application, 23, 163-185.

van Huis, A., Dicke, M., van Loon, J.J.A. (2015). Insects to feed the world. Journal of Insects as Food and Feed, 1, 3-5.

van Raamsdonk, L. W. D., van der Fels-Klerx, H. J. \& de Jong, J. (2017). New feed ingredients: the insect opportunity. Food additives \& contaminants: part A, 34 (8), 1384-1397.

Verbeke, W. (2015). Profiling consumers who are ready to adopt insects as a meat substitute in a Western society. Food Quality and Preference, 39, 147-155.

Verbeke, W., Spranghers, T., De Clercq, P., De Smet, S., Sas, B. \& Eeckhout, M. (2015). Insects in animal feed: Acceptance and its determinants among farmers, agriculture sector stakeholders and citizens. Animal Feed Science and Technology, 204, 72-87.

Veys, P. \& Baeten, V. (2018). Protocol for the isolation of processed animal proteins from insects in feed and their identification by microscopy. Food Control, 92, 496-504.

Wang, D., Zhai, S.W., Zhang, C. X., Zhang, Q. \& Chena, H. (2007). Nutrition value of the Chinese grasshopper Acrida cinerea (Thunberg) for broilers. Animal Feed Science and Technology, 135, 66-74.

Wang, H., Rehman, K., Xiu Liu, Yang, Q., Zheng, L., Li, W., Cai, M., Li, Q., Zhang, J. \& Yu, Z. (2017). Biotechnology for Biofuels, 10, 304-317.

Yen, A. L. (2009). Edible insects: Traditional knowledge or western phobia? Journal of Entomological Research, 39, 289-298.

Zagon, J., di Rienzo, V., Potkura, J., Lampen, A. \& Braeuning, A. (2018). A real-time PCR method for the detection of black soldier fly (Hermetia illucens) in feedstuff. Food Control, 91, 440-448. 